\title{
Determinants and impact of asthma disease in Mymensingh zone: An empirical analysis
}

\author{
Homayora Yeasmin ${ }^{1}$, Sheikh Mohammad Sayem ${ }^{2}$, ${ }_{\text {Farjana Misu }}^{2}$ and Mohammad Amirul Islam ${ }^{2}$ \\ ${ }^{1}$ Food and Agriculture Organization of the United Nations (FAO), Bangladesh \\ ${ }^{2}$ Department of Agricultural Statistics, Faculty of Agricultural Economics and Rural Sociology, Bangladesh Agricultural \\ University, Mymensingh-2202, Bangladesh
}

\begin{tabular}{l}
\hline ARTICLE INFO OPENOACCES \\
\hline Article history: \\
Received: 09 May 2018 \\
Accepted: 08 December 2018 \\
Published: 31 December 2018 \\
\hline Keywords: \\
Asthma; hypertension; weight \\
change; allergic reaction \\
\hline Correspondence: \\
Farjana Misu \\
凶: farjana5100@ gmail.com
\end{tabular}

Copyright:

(C2018 by authors and BAURES. This work is licensed under the Creative Commons Attribution International License (CC By 4.0).

\section{Introduction}

Asthma is defined as a chronic inflammatory disease of the respiratory tract, characterized by coughing, wheezing, breathlessness, airway obstruction, chest tightness, and bronchial hyper-responsiveness (WAO, 2015). These symptoms are considered as the primary indicators that a patient is suffering from the respiratory disorder. There are many factors involved in the development of asthma, including a combination of genetic, lifestyle, habit, environmental and socioeconomic factors which are not cared about by many of us. Irritation by smoke, fumes, strong smells, or exercise, breathlessness worsening at night, and responding to appropriate asthma therapy are symptoms that strongly suggest the presence of asthma (GINA, 2012). Among various infectious agents, attack of respiratory syncytial virus (RSV) in early stage of life is well known to cause asthma in later life (Henderson et al., 2005). Increased temperature and carbon emission result in increased production of pollens and fungal spores that could exacerbate symptoms of allergic diseases (Beggs, 2004). The prevalence of asthma symptoms in cities with well-known high levels of air pollution was much higher than places with significantly lesser pollution (Mallol, 2008). The passive smoking could well be the most important 'non-communicable' environmental factor involved in the etiology of early asthma (Sarkaret al., 2012).The high prevalence of asthma may be related to a diet characterized by lower consumption of fresh fruits, vegetables and fish, and high consumption of foods rich in saturated fatty acids, sugars, and salt (Woolcock, 1996). The morbidity from asthma have shown an upward trend during an era when quality medications are easily available for asthma (Alderson, 1987). Rapid advances in several fields, especially in molecular biology and statistical analysis have allowed the increased understanding of the development of chronic diseases but a clear picture of the mechanisms that lead to asthma onset and persistence is still lacking (Mapp, 2003). As a chronic disease it can also affect other chronic diseases which should be clear through this study. It is estimated that as many as 300 million people of all ages, and all ethnic backgrounds, suffer from asthma and the burden of this disease to governments, health care systems, families, and patients has been increasing worldwide and there may be an additional 100 million persons with asthma by 2025 (Masoliet al., 2004; Doughertyand Fahy, 2009).

In Bangladesh, asthma appears to be a substantial public health problem. It is recognized as an important cause of morbidity, economic loss, and mortality (Goodwin, 2007). Asthma is associated with enormous healthcare expenditures that include both direct and indirect costs. It is also associated with the loss of future potential earnings due to both morbidity and mortality (Bahadori 
et al., 2009). As a result it has become an important topic of consideration for the developing countries.

Mymensingh is one of the asthmatic regions of Bangladesh. Prevalence of asthma is high in this area. Moreover, people in our country, especially city people, are not too conscious to take care of chronic diseases like asthma. Actually they do not have any clear idea about the risk factors and management procedure. There has been a very few studies that identifiedthe risk factors and management procedure of asthma disease especially in Mymensingh zone.

The primary objectives of this study are to i) find out the influential factors of asthma disease in Mymensingh zone, ii) diagnose the effect of asthma disease on other chronic diseases, and iii) recommend management and treatment policies for asthmatic patients.

\section{Materials and Methods}

\section{Survey design}

The study has been conducted in different government hospitals, diagnostic centers, doctors' personal chambers, situated in the sadarupazilas of the districts in greater Mymensingh. The greater Mymensingh zone includes Mymensingh, Kishoreganj, Netrokona, Jamalpur, Sherpur and Tagail. These districts have been selected as the study area of this research from where the information about 100 asthmatic patients has been collected through cluster sampling. From Mymensingh, Kishoreganj, Netrokona, Jamalpur, Sherpur and Tagail districts, 30, 25, 15, 10, 10, 10 samples have been collected respectively.The clusters are the centers like hospitals and doctor's chamber where the patients gather for treatment. After explaining the purpose of the study to the respondents and obtaining their verbal consent, the respondents have been interviewed using a predesigned interview schedule.

\section{Variable assessment}

Variables included in this study aredisease status of asthma, different socio- demographicand socioeconomic factors, e.g., age, gender, marital status, occupation, permanent residence, education level, income, expenditure, savings, expenditure on food and level of occupation, different biological factors, e.g., height, weight, weight change, type of change in weight (increase or decrease), parents' children asthma,symptoms of asthma, presence of allergic reaction, allergy type, presence of different diseases (hypertension, diabetes, cardiovascular diseases, kidney diseases), different habits (food habit, smoking habit), factors related with housing place, e.g., accessibility of sunlight into home, medium of cooking, presence of smokers into home, having pet animal, presence of cockroaches, mice, or rats, usage of carpet, and presence of ventilator in the bathroom, factors related with working place, e.g., presence of allergens, comfortability, smoking allowance, information about job change, different indicators of health, e.g., body mass index (BMI), blood pressure, and different type of diseases the respondents are suffering from. The disease status of asthma is ordinal in nature and categorized on the basis of the times of medicine taken by the asthmatic patients daily. Patients taking medicine once, twice and thrice a day are categorized as mild asthmatic patients, moderate asthmatic patients and severe asthmatic patients respectively. In the analyses of the determinants of disease status of asthmatic patients different biological and socio-economic variables have been taken as factors and covariates. To assess the impact of asthma disease in Mymensingh zone different health related indicators, e.g., weight change and presence of hypertension have been taken as vector of dependent variable. Some recommendations of management policy for asthmatic patients have been identified by specialists' suggestions.

\section{Statistical analysis}

Strength of the relationship between disease status of asthma and different socio-economic and biological factors has been tested through Chi-Square at 5\% level of significance. To find out the determinants of asthma diseasemultinomial logistic regression has been used on the basis of the pattern of the response variable. Different chronic disease (hypertension, weight change) are jointly influenced by severe asthma disease. Hence multivariate logistic regression could perform better than univeriate logistic regression. That's why; the impact of asthma on other chronic diseases has been investigated by using multivariate logistic regression. In this study SPSS 20 has been used to analyze the data.

\section{Results}

The analyses reveal significant association between disease status of asthma and different factors like weight change ( $p=0.032)$, patients' children asthma $(p=0.028)$, symptoms of asthma $(p=0.015)$, presence of other diseases $(p=0.006)$, normal food habit $(p=0.006)$, presence of allergic reaction $(p=0.023)$, presence of hypertension $(p=0.045)$, smoking allowed in the working place $(p=0.007)$, presence of asthmatic factors in the working place $(p=0.011)$, accessibility of sunlight into home $(p=0.018)$, presence of cockroaches, mice or rats $(p<0.001)$ [Table 1].

Table 1. Measures of association between disease status of asthma and different risk factors

\begin{tabular}{lcc}
\hline Variables or Attributes & \multicolumn{2}{c}{ Pearson Chi-Square } \\
\cline { 2 - 3 } & Value & P -value \\
\hline Weight change & 6.894 & .032 \\
Patients' children asthma & 10.853 & .028 \\
Symptoms of asthma & 19.029 & .015 \\
Presence of other diseases & 30.934 & .006 \\
Normal food habit & 11.377 & .006 \\
Presence of allergic reaction & 10.916 & .023 \\
Presence of hypertension & 6.217 & .045 \\
Smoking allowed in the working place & 14.032 & .007 \\
Presence of asthmatic factors in the & 9.07 & .011 \\
working place & & \\
Accessibility of sunlight into home & 8.069 & .018 \\
Presence of cockroaches, mice or rats & 24.522 & .000 \\
\hline
\end{tabular}

Note: $\mathrm{p}<0.05$ indicates significant relationship. 
About $70 \%$ of the respondents reported that there was no strict practice of anti-smoking law in their work places[tablenot shown]. The regression analysis result suggests that the likelihood of being in severe asthma is5.182 times higher if the public rule of smoking is not maintained in work place when compared to patients without asthmatic health condition. Furthermore, the analysisreveals that the likelihood of being in severe asthma is $94.6 \%$ less if there is access to sunlight through the living rooms of the patients when compared to patients without asthmatic health condition [Table 2].

Table 2. Multinomial logistic regression estimates of the effects of different determinants of asthma disease

\begin{tabular}{|c|c|c|c|c|}
\hline $\begin{array}{c}\text { Disease status of } \\
\text { Asthma }\end{array}$ & Independent Variables & $\mathbf{B}$ & Standard Error & Odds Ratio \\
\hline \multirow{8}{*}{$\begin{array}{l}\text { Moderate } \\
\text { (r: Mild) }\end{array}$} & Intercept & 19.849 & 1.679 & \\
\hline & $\begin{array}{l}\text { Yes } \\
\text { Yecessiominty (I. NO) }\end{array}$ & $-2.668^{*}$ & 1.183 & 0.069 \\
\hline & Smoking allowed in the working place (r: No) & & & \\
\hline & Yes & -1.374 & 1.972 & 0.253 \\
\hline & $\begin{array}{c}\text { Not maintained } \\
\text { Allergic reaction (r: No) }\end{array}$ & $1.6456^{* *}$ & 0.892 & 5.182 \\
\hline & Yes & -15.840 & 1.034 & $1.320 \mathrm{E}-007$ \\
\hline & $\begin{array}{c}\text { Cockroaches, mice, or rats in home } \\
\text { (r: Sometimes) }\end{array}$ & & & \\
\hline & Yes & $-1.566^{* *}$ & 0.950 & 0.032 \\
\hline \multirow{10}{*}{$\begin{array}{l}\text { Severe } \\
\text { (r: Mild) }\end{array}$} & Intercept & 19.778 & 1.491 & \\
\hline & Accessibility of sunlight (r: No) & & & \\
\hline & Yes & $-2.925^{*}$ & 1.259 & 0.054 \\
\hline & Smoking allowed in the working place (r: No) & & & \\
\hline & Yes & -1.798 & 2.362 & 0.166 \\
\hline & Not maintained & 1.439 & 1.013 & 4.215 \\
\hline & Allergic reaction (r: No) & & & \\
\hline & Yes & 1.439 & 0.001 & $1.492 \mathrm{E}-008$ \\
\hline & Cockroaches, mice, or rats in home (r: No) & & & \\
\hline & Yes & 0.044 & 1.098 & 1.045 \\
\hline
\end{tabular}

Note: * and ** indicate significance at 0.05 and 0.01 probability level respectively.

The results form sample observation also suggest that the likelihood of being in severeasthma will increase by $4.5 \%$ if cockroaches, mice or rates are permanently present in the room when compared to patients without asthmatic health conditionThough the likelihood of being in moderate asthma will decrease by $96.8 \%$ if cockroaches, mice or rates are permanently present in the room [Table 2].Researchers found higher concentrations of cockroach, mice and cat allergens present in dust samples collected from the children's homes during the first three years of life - at age three months, two years and three years - were linked to a lower risk of asthma by age seven. (O'Connor et al., 2018). In our study, it has been found that other factors rather than hereditary factor are more responsible for the development of this disease and it is true for most of the patients in Mymensingh area.

Almost $41 \%$ asthmatic patients have been found to suffer from hypertension [Table not shown]. The multivariate logistic regression suggests that hypertension and weight change both are significantly $(p<0.01)$ influenced by disease status of asthma disease [Table 3].

Table 3. Multivariate logistic regression estimates of the impact of asthma on other biomedical factors

\begin{tabular}{|c|c|c|c|c|}
\hline $\begin{array}{l}\text { Dependent } \\
\text { Variable }\end{array}$ & Parameter & B & Std. Error & Odds Ratio \\
\hline \multirow{2}{*}{$\begin{array}{l}\text { Presence of } \\
\text { hypertension }\end{array}$} & $\begin{array}{c}\text { Intercept } \\
\text { Disease status of asthma } \\
\text { (r: Severe asthmatic patient) }\end{array}$ & $1.833^{* *}$ & .138 & 6.25 \\
\hline & $\begin{array}{l}\text { Moderate asthmatic patient } \\
\text { Mild asthmatic patient }\end{array}$ & $\begin{array}{l}-.377^{* *} \\
.167 \\
\end{array}$ & $\begin{array}{l}.155 \\
.366\end{array}$ & $\begin{array}{l}0.686 \\
1.182 \\
\end{array}$ \\
\hline Weight change & $\begin{array}{c}\text { Intercept } \\
\text { Disease status of asthma } \\
\text { (r: Severe asthmatic patient) } \\
\text { Moderate asthmatic patient } \\
\text { Mild asthmatic patient }\end{array}$ & $\begin{array}{l}-.065 \\
-.500^{* *} \\
\end{array}$ & $\begin{array}{l}.078 \\
.184\end{array}$ & $\begin{array}{r}-.836 \\
-2.719 \\
\end{array}$ \\
\hline
\end{tabular}

Note: $* *$ indicates significance at 0.01 probability level. 


\section{Discussion}

The present world is troubled with a plethora of chronic diseases and asthma is one of them. Bangladesh is also facing a great problem with this disease. Here, a large number of people are suffering from asthma and also the number of sufferers has been increasing gradually. Among the most serious asthmatic zones, Mymensingh is significantly remarkable. Here people of various ages, classes and occupations are found to be plagued with this common disease. Like other studies the analyses suggests that presence of asthmatic factors in the working place, accessibility of sunlight (Kamranet al., 2015), smoking allowance in the working place (Godtfredsenet al., 2001), allergic reaction (Khanet al., 2006), presence of cockroaches (Kanget al., 1979), mice or rats, heredity components have been found to be associated with the prevalence of asthma. These factors are more or less identified in other studies (GINA, 2012). It has been also examined that asthma influencespositively the presence of diseases especially hypertension, and change in body weight (Masoliet al., 2004; Doughertyand Fahy, 2009).

\section{Conclusion}

This study attempts to understand the determinants and impact of asthma in Mymensingh zone of Bangladesh using statistical techniques. The findings of this research corroborate with other studies and identified some important determinants of asthma, e.g., accessibility of sunlight, smoking allowance in the working place, allergic reaction, and presence of cockroaches, mice, or rats.Also asthma is found to have significant influence on hypertension and changing of weight. The analysis will guide the policy planners and health professionals to address the issue properly in a systematic manner. Mymensingh zone as being an asthmatic region needs proper attention with tailored policy interventions formulated based on the findings of this research. Building awareness regarding healthy household condition and smoking free office environment may be useful steps towards controlling the disease.

\section{Acknowledgements}

The authors of this manuscript gratefully acknowledge the kind support of the doctors and asthma patients of different study hospitals and doctor's chambers. This research was conducted under the National Science and Technology (NST) Fellowship 2014-15 of the first author. Such valuable support is also gratefully acknowledged.

\section{References}

Alderson M 1987: Trends in morbidity and mortality from asthma. Population Trends $4918-23$.

Bahadori K, Doyle-Waters MM, Marra C, Lynd L, Alasaly K, Swiston J, FitzGerald JM 2009: Economic burden of asthma: a systematic review. BMC Pulmonary Medicine, 9:24. https://doi.org/10.1186/1471-2466-9-24 PMid:19454036 PMCid:PMC2698859

Beggs PJ 2004: Impacts of climate change on aeroallergens: past and future. Journal of Clinical\&Experimental Allergy 34 1507-1513. https://doi.org/10.1111/j.1365-2222.2004.02061.x

Dougherty RH, Fahy JV 2009. Acute exacerbations of asthma: epidemiology, biology and the exacerbation prone phenotype. ClinExp Allergy 39(2) 93-202. https://doi.org/10.1111/j.1365-2222.2008.03157.x PMid:19187331 PMCid:PMC2730743

Global Initiative for Asthma (GINA) 2012: Global strategy for asthma management and prevention.

Godtfredsen NS, Lange P, Prescott E, Osler M, Vestbo J 2001: Changes in smoking habitsand risk of asthma: a longitudinal population based study. European RespiratoryJournal18 549-554. https://doi.org/10.1183/09031936.01.00100801 PMid:11589354

Goodwin RD 2007: Environmental tobacco smoke and the epidemic of asthma in children: the role of cigarette use. Annals of Allergy, Asthma \& Immunology 98 (5) 447454. https://doi.org/10.1016/S1081-1206(10)60759-4

Henderson J, Granell R, Heron J 2005: Associations of wheezing phenotypes in the first 6 years of life with atopy, lung function and airway responsiveness in mid-childhood. Thorax 63 974-980. https://doi.org/10.1136/thx.2007.093187 PMid:18678704 PMCid:PMC2582336

Kamran A, Hanif S, Murtaza G 2015: Risk factors of childhood asthma in children attending Lyari General Hospital. Journal of Pakistan Medical Association, 65:647. PMid:26060164

Kang B, Vellody D, Homburger H, Younginger JW 1979. Cockroach as a cause of allergic asthma: Its specificity and immunologic profile. J Allergy ClinImmunol, 63 80-86. https://doi.org/10.1016/0091-6749(79)90196-9

Khan A, Braback L, Ekeus C, Hjern A, Forsberg B 2006: Maternal obesity during pregnancy as a risk for kitchen ventilation, and asthma, allergic symptom and ensitization in young children the PIAMA study. Journal of Allergy 61 563-568. https://doi.org/10.1111/j.1398-9995.2006.01037.x PMid:16629785

Mallol J 2008: Asthma in Latin America: where the asthma causative/protective hypotheses fail. Journal of Allergy and Clinical Immunology 36 150-153.

Mapp, CE 2003: The role of genetic factors in occupational asthma. European Respiratory Journal 22(1) 173-178. https://doi.org/10.1183/09031936.03.00011003 PMid:12882468

Masoli M, Fabian D, Holt S, Beasley R 2004: The global burden of asthma: executive summary of the GINA Dissemination Committee report. Journal of Allergy 59 469-478.

https://doi.org/10.1111/j.1398-9995.2004.00526.x PMid:15080825

O'Connor GT, Lynch SV, Bloomberg GR, Kattan M, Wood RA, Gergen PJ, Jaffee KF, Calatroni A, Bacharier LB, Beigelman A, Sandel MT, Johnson CC, Faruqi A, Santee C, Fujimura KE, Fadrosh D, Boushey H, Visness CM, Gern JE 2018. Early-life home environment and risk of asthma among inner-city children. The Journal of allergy and clinical immunology 141(4) 1468-1475. https://doi.org/10.1016/j.jaci.2017.06.040 PMid:28939248

Sarkar S, Song Y, Sarkar S, Kipen HM, Laumbach RJ, Zhang J, Strickland PAO, Gardner CR, Schwander S 2012: Suppression of the NF-jB pathway by diesel exhaust particles impairs human antimycobacterial immunity. Journal of Immunology 188 2778-2793.

https://doi.org/10.4049/jimmunol.1101380 PMid:22345648 PMCid:PMC3293992

WAO-World Allergy Organization. A World Federation of Allergy, Asthma \&Clonical Immunology Societies. Allergic Asthma: Symptoms and Treatment, 2015.

Woolcock AJ 1996: Asthma--disease of a modem lifestyle. Medical Journal of Australia 165 358-359. PMid: 8890840 